\title{
Functional capacity and quality of life of hospitalized octogenarians
}

\author{
Capacidade funcional e qualidade de vida de octogenários hospitalizados \\ Capacidad funcional y calidad de vida de octogenarios hospitalizados
}

\section{Michelle Cardoso Billett' \\ ORCID: 0000-0001-7201-9606}

Cássia Regina Vancini Campanharo' ORCID: 0000-0002-7688-2674

Maria Carolina Barbosa Teixeira Lopes' ORCID: 0000-0002-8989-4404

Ruth Ester Assayag Batista' ORCID: 0000-0002-6416-1079

Angélica Gonçalves Silva Belasco' ORCID: 0000-0002-0307-6225

Meiry Fernanda Pinto Okuno' ORCID: 0000-0003-4200-1186

'Universidade Federal de São Paulo. São Paulo, São Paulo, Brazil.

How to cite this article:

Billett MC, Campanharo CRV, Lopes MCBT, Batista REA,

Belasco AGS, Okuno MFP. Functional capacity and quality of life of hospitalized octogenarians.

Rev Bras Enferm. 2019;72(Suppl 2):43-8.

doi: http://dx.doi.org/10.1590/0034-7167-2017-0781

Corresponding Author:

Cássia Regina Vancini Campanharo

E-mail:cvancini@unifesp.br

Submission: 12-06-2017

Approval: 06-28-2018

\begin{abstract}
Objective: To evaluate the ability to perform activities of daily living (ADL) and to correlate functional capacity with quality of life (QoL) of hospitalized octogenarians. Method: A crosssectional study with 128 patients using the quality of life instruments WHOQOL-OLD and WHOQOL-BREF and the Katz Scale. Results: The majority of patients was fully dependent; patients with higher schooling had less independence; older adults with partial dependence and independence had higher scores in perceived QoL; in the domains of autonomy, past, present and futureactivities; and better overall QoL than those with full dependence. Partially dependent patients had higher scores in the death and dying domain than independent patients. Conclusion: Older adults' QoL is associated with the maintenance of autonomy and functional capacity. Older adults experience a health decline during the hospitalization process, due to the limitation in performing their $A D L$ and lack of encouragement by the health team.
\end{abstract}

Descriptors: Aged; Hospitalization; Geriatric Nursing; Quality of Life; Aging.

\section{RESUMO}

Objetivo: avaliar capacidade de desenvolver atividades de vida diária (AVD) e correlacionar capacidade funcional com a qualidade de vida (QV) dos octogenários hospitalizados. Método: estudo transversal com 128 pacientes, utilizando os instrumentos de qualidade de vida WHOQOL-OLD e WHOQOL-BREF e a Escala de Katz. Resultados: a maioria apresentou grau máximo de dependência; pacientes com maior escolaridade tiveram menor independência; idosos com dependência parcial e independência tiveram maiores escores na percepção da QV; nos domínios autonomia, atividades passadas, presentes e futuras; e melhor QV geral comparados àqueles com grau máximo de dependência. Os com dependência parcial apresentaram maiores escores no domínio morte e morrer quando comparados aos independentes. Conclusão: a QV dos idosos associa-se à manutenção da autonomia e à capacidade funcional. Existe um declínio na saúde do idoso durante o processo de hospitalização, devido à limitação em realizar suas AVD e à falta de estímulo por parte da equipe de saúde.

Descritores: Idoso; Hospitalização; Enfermagem Geriátrica; Qualidade de Vida; Envelhecimento.

\section{RESUMEN}

Objetivo: evaluar la capacidad de realizar actividades de vida diaria (AVD) y correlacionar la capacidad funcional con la calidad de vida (CV) de octogenarios hospitalizados. Método: estudio transversal con 128 pacientes, en que se utilizó los instrumentos de calidad de vida WHOQOL-OLD y WHOQOL-BREF y la Escala de Katz. Resultados: la mayoría presentó un grado máximo de dependencia; los pacientes con mayor escolaridad tuvieron menor independencia; los ancianos con dependencia parcial e independencia tuvieron mayores puntajes en la percepción de la CV en los dominios autonomía, actividades pasadas, presentes y futuras; y mejor CV general comparados a aquellos con grado máximo de dependencia. Los ancianos con dependencia parcial presentaron mayores puntajes en el dominio muerte y morir al compararse a los independientes. Conclusión: la CV de los ancianos estuvo asociada al mantenimiento de la autonomía y a la capacidad funcional. Hubo un empeoramiento de la salud del anciano durante el proceso de hospitalización, debido a la limitación en realizar sus AVD y a la falta de estímulo por parte del equipo de salud para hacerlas.

Descriptores: Anciano; Hospitalización; Enfermería Geriátrica; Calidad de Vida; Envejecimiento. 


\section{INTRODUCTION}

According to the World Health Organization (WHO), it is estimated that there are more than 605 million people over 60 years of age in the world. The proportion of older adults will increase in the coming decades, and by 2025 it is estimated that there will be 1.2 billion elderly people worldwide and two out of three will live in developing countries ${ }^{(1)}$.

In Brazil there is also a significant increase in this contingent, impacting society and consequently demanding adjustments in physical and social structures according to the demands of the population. The number of long living people, i.e. aged 80 years or more, has been increasing very fast, constituting the fastest growing population segment in recent times. In 2014 they were 3.2 million and in the year 2060 the number will get close to 19 million people, indicating a growth of $500 \%{ }^{(2)}$.

Human aging is a process characterized by the gradual loss of physical and cognitive capacities, and maintenance of functional independence to the end of life is, and will continue to be, the most ambitious goal of geriatrics ${ }^{(1)}$.

Functional disability is associated with a higher risk of hospital readmission, admission to a long-term institution, worse outcome after surgery, postoperative complications, increased risk of falls, dementia, morbidity and mortality in general. It can be potentially reversible if a specific intervention, such as rehabilitation and exercise, is performed ${ }^{(1)}$.

In an aging society, new alternatives have to be established that can somehow meet the needs of the aged, increasing the perceived quality of life ${ }^{(1)}$.

Functional ability refers to an individual's living conditions that allow him or her to interact independently with the environment. Thus, functional capacity assessment allows to determine older adults' independence in basic and instrumental activities, such as: bathing, dressing, personal hygiene, moving, eating, maintaining continence, preparing meals, controlling finances, taking medicines, cleaning the house, shopping, using public transportation, using the telephone, and walking some distance ${ }^{(3)}$.

As functional capacity decreases with age, it becomes necessary to create strategies aimed at the promotion, treatment and rehabilitation of the elderly, in order to reintegrate them socially ${ }^{(3)}$.

QoL in old age is linked to perceptions of physical and mental health and its correlations with risks and health conditions, functional and economic status, and social support. All these factors are interrelated and their relative importance differs according to society and the individual ${ }^{(4)}$.

The investigation of QoL and functional capacity in octogenarians is of great importance to understand the limits of aging, as well as its association with well-being and the disease itself, thus enabling a favorable intervention in relation to the decline of functions in the aged, providing greater well-being and better maintenance of functional capacity and QoL during this life stage that demands so much care ${ }^{(5)}$.

By knowing the QoL domains related to octogenarians' functional capacity and degree of dependence, we can identify demands for nursing care and the multidisciplinary team that, once worked on, can minimize or avoid the loss of functional capacity, prevent complications and improve these older adults' QoL.

\section{OBJECTIVE}

To evaluate the capacity to perform activities of daily living (ADL) and to correlate functional capacity with hospitalized octogenarians' QoL.

\section{METHOD}

A cross-sectional and analytical epidemiological study, carried out at Hospital São Paulo (HSP) - which is the teaching hospital of the Federal University of São Paulo (Unifesp) -, in clinical, surgical and emergency units between June 2016 and April of 2017. The study included 128 older adults with at least three days of hospitalization ${ }^{(6)}$, age from 80 years, able to understand and respond to the questionnaires, who had no medical record of dementia and who agreed to participate in the study and signed the Free and Informed Consent Form.

The sample size was calculated using the stratified probabilistic sampling method proportional to the average number of patients from 80 years of age, hospitalized in the six months prior to the study. The calculation considered a confidence level greater than or equal to $80 \%$ and alpha of $5 \%$, based on the characteristics of age, gender, schooling, marital status, occupation, hospitalization days, family income, medication use, caregiver and religion. The result indicated the that 100 patients should be included in the study to achieve the proposed goals.

To obtain the data, we used a structured questionnaire with information about age, gender, skin color, schooling, marital status, occupation, hospitalization days, family income, caregiver presence and comorbidities.

The World Health Organization Quality of Life for Older Persons (WHOQOL-OLD), specific for use in the elderly population, and its short version WHOLQOL-BREF, a generic instrument for assessing QoL, were used for QoL measurement. Both instruments were translated into Portuguese and validated for use in the Brazilian elderly population ${ }^{(7-8)}$.

The WHOQOL-OLD consists of 24 items divided into six domains: sensory abilities; autonomy; past, present and future activities; social participation; death and dying; and intimacy. The final scores for each domain can range from 0 to 100 points. The closer to 100 , the better the QoL.

WHOLQOL-BREF has 26 items, the first two refer to self-perceived QoL and health satisfaction. The remaining 24 questions represent each of the 24 facets that comprise the original instrument, divided into four domains: physical, psychological, social relationships and environment. The final scores for each domain can range from 0 to 100 points. The closer to 100, the better the QoL.

The Katz Scale was used to assess ability to perform ADL, which measures the individual's performance and degree of dependence in six items of self-care activities: feeding, sphincter control, transfer, personal hygiene, capacity to get dressed and to take a shower. For classification in the level of dependence, the elderly were categorized into independent (six points), partially dependent (from three to five points) and fully dependent (zero to two points) ${ }^{(9)}$.

The list of patients aged 80 years and over who were admitted to clinical and surgical units and the emergency department of the HSP was requested daily. Then the researcher visited each facility, consulted the medical records to verify the octogenarian's ability to understand and respond to the research questionnaires and 
instruments and if he/she was already hospitalized for at least three days, and then directly contacted the patient to check if he/she met the other inclusion criteria. Confirmed octogenarians were invited to take part in the study, and if so they were interviewed individually. The instrument was read by the researcher at a single moment, with an average duration of 40 minutes.

Descriptive analysis was used for sociodemographic and economic characterization, as well as days of hospitalization, caregiver presence and comorbidities. For the continuous variables we calculated the mean, standard deviation, median, minimum and maximum, and for categorical variables, frequency and percentage. Analysis of Variance was used to relate functional capacity to QoL. The level of significance adopted was $p<0.05$ and the Statistical Package for the Social Sciences, version 19, was used in the statistical analysis.

This study was approved by the Research Ethics Committee of Unifesp (CAAE: 53904316.6.0000.5505).

\section{RESULTS}

Patient age ranged from 80 to 95 years, days of hospitalization from 3 to 42, with a predominance of the female gender, white skin color, widowed, retired or pensioner, illiterate or incomplete elementary school, income between one and two minimum wages, with caregiver and presence of comorbidities, with hypertension (94.5\%), diabetes mellitus (38.3\%) and cardiopathy (35.9\%) the most frequent, as shown in Table 1.

It can be seen in Table 2 that respondents' mean score in the Katz Scale was $3(S D=2.16)$, median $3(0-6)$ and the majority was fully dependent.

Female older adults showed a higher percentage of full dependence and a lower percentage of independence than male older adults $(p=0.0177)$.

Patients with complete high school and higher education had a lower percentage of independence and a higher percentage of full dependence; and those with complete elementary school had a lower percentage of partial dependence and a higher percentage of full dependence $(p=0.0435)$.

Table 3 shows that older adults with partial dependence and independence had higher scores in the WHOQOL-BREF physical, psychological and environmental domains than those with full dependence.

Patients with partial dependence had higher scores on perceived QoL than those with full dependence.

The elderly with partial dependence presented higher scores in sensory functioning and social participation domains than those with full dependence.

Patients with partial and independent dependence had higher scores in autonomy, past, present and future activities, and general QoL domains than those with full dependence.

Study participants with partial dependence had higher scores in the death and dying domain than the independent ones, as shown in Table 4.
Table 1 - Sociodemographic, economic, and clinical characteristics and caregiver presence of hospitalized elderly, São Paulo, Brazil, 2017

\begin{tabular}{|c|c|}
\hline Characteristics & $N=128$ \\
\hline Age (years) ${ }^{*}$ & $83(80-95)$ \\
\hline \multicolumn{2}{|l|}{ Gender ${ }^{\dagger}$} \\
\hline Male & $47(36.7)$ \\
\hline Female & $81(63.3)$ \\
\hline \multicolumn{2}{|l|}{ Skin color ${ }^{\dagger}$} \\
\hline White & $96(75.0)$ \\
\hline Black & $15(11.7)$ \\
\hline Brown & $14(10.9)$ \\
\hline Yellow & $3(2.4)$ \\
\hline \multicolumn{2}{|l|}{ Marital status $^{\dagger}$} \\
\hline Widowed & $68(53.1)$ \\
\hline Married & $43(33.6)$ \\
\hline Single, Divorced & $17(13.3)$ \\
\hline \multicolumn{2}{|l|}{ Occupation $^{\dagger}$} \\
\hline Retired/Pensioner & $121(94.5)$ \\
\hline Housewife & $5(3.9)$ \\
\hline Self-employed & $2(1.6)$ \\
\hline \multicolumn{2}{|l|}{ Schooling ${ }^{\dagger}$} \\
\hline Illiterate/incomplete elementary school & $66(51.6)$ \\
\hline Elementary School & $44(34.4)$ \\
\hline High school & $12(9.4)$ \\
\hline College & $6 \quad(4.7)$ \\
\hline \multicolumn{2}{|l|}{ Family income (reais) $^{\dagger}$} \\
\hline Up to 1 minimum wage & $31(24.2)$ \\
\hline $1-2$ minimum wages & $53(41.4)$ \\
\hline 2-3 minimum wages & $28(21.9)$ \\
\hline 3-4 minimum wages & $6(4.7)$ \\
\hline 4-5 minimum wages & $5 \quad(3.9)$ \\
\hline$>5$ minimum wages & $5 \quad(3.9)$ \\
\hline \multicolumn{2}{|l|}{ Caregiver $^{\dagger}$} \\
\hline No & $23(18.0)$ \\
\hline Yes & $105(82.0)$ \\
\hline Days of hospitalization* & $3(3-42)$ \\
\hline \multicolumn{2}{|l|}{ Comorbidities $^{\dagger}$} \\
\hline No & $7(5.5)$ \\
\hline Yes & $121(94.5)$ \\
\hline
\end{tabular}

Note: *Median (maximum-minimum values), tFrequency and percentage.

Table 2 - Dependence levels according to Katz Scale scores of hospitalized octogenarians, São Paulo, Brazil, 2017

\begin{tabular}{lc}
\hline Katz & $\mathbf{N}=\mathbf{( 1 2 8 )}$ \\
\hline Mean (SD) & $3(2.16)$ \\
Median (minimum-maximum) & $3(0-6)$ \\
Fully dependent $^{\dagger}$ & $60(46.9)$ \\
Partially dependent $^{\dagger}$ & $41(32.0)$ \\
Independent $^{\dagger}$ & $27(21.1)$ \\
\hline
\end{tabular}

Note: + Frequency and percentage, $S D$ = standard deviation.

Table 3 - Correlation between dependence levels assessed by the Katz Scale and WHOQOL-BREF domain, São Paulo, Brazil, 2017

\begin{tabular}{lcccccc}
\hline $\begin{array}{c}\text { WHOQOL-BREF - } \\
\text { mean (SD) }\end{array}$ & Full Dependence & Partial dependence & Independence & Total & K value \\
\hline Physical domain & $38.21(13.29)$ & $48.52(15.87)$ & $55.03(13.45)$ & $45.06(15.67)$ & $<\mathbf{0 . 0 0 0 1}$ \\
Psychological domain & $52.64(16.31)$ & $64.43(14.01)$ & $62.04(10.80)$ & $58.40(15.48)$ & 0.0003 \\
Social relationships & $64.44(15.86)$ & $64.23(17.90)$ & $71.60(11.62)$ & $65.89(15.94)$ & 0.1181 \\
Environment & $52.66(11.23)$ & $60.21(11.63)$ & $62.04(8.30)$ & $57.06(11.53)$ & 0.0001 \\
Perception of QoL & $2.98(0.98)$ & $3.56(0.67)$ & $3.41(0.84)$ & $3.26(0.90)$ & 0.0112 \\
Health satisfaction & $2.62(0.99)$ & $2.93(1.10)$ & $3.11(0.97)$ & $2.82(1.04)$ & 0.0906 \\
Total patients & 60 & 41 & 27 & 128 & \\
& & & & & &
\end{tabular}

Note: Analysis of Variance was used, SD = standard deviation 
Table 4 - Correlation between dependence levels assessed by the Katz Scale and WHOQOL-OLD domains, São Paulo, Brazil, 2017

\begin{tabular}{lccccc}
\hline \multicolumn{1}{c}{$\begin{array}{c}\text { WHOQOL-OLD - } \\
\text { mean (SD) }\end{array}$} & Full Dependence & Partial dependence & Independence & Total & p value \\
\hline Sensory functioning & $41.46(21.65)$ & $63.87(18.88)$ & $52.78(22.89)$ & $51.03(23.12)$ & $<\mathbf{0 . 0 0 0 1}$ \\
Autonomy & $40.42(21.85)$ & $57.16(17.15)$ & $54.40(14.27)$ & $48.73(20.46)$ & $<\mathbf{0 . 0 0 0 1}$ \\
Past, present and future activities & $54.38(17.23)$ & $65.40(17.40)$ & $66.20(13.79)$ & $60.40(17.45)$ & 0.0006 \\
Social participation & $47.92(18.72)$ & $58.08(19.02)$ & $58.10(19.21)$ & $53.32(19.45)$ & 0.0124 \\
Death and Dying & $54.79(29.21)$ & $66.31(27.63)$ & $48.38(25.75)$ & $57.13(28.61)$ & 0.0368 \\
Intimacy & $68.75(18.80)$ & $68.14(17.28)$ & $75.46(17.33)$ & $69.97(18.11)$ & 0.1417 \\
General QoL & $51.28(13.32)$ & $63.16(11.89)$ & $59.22(12.39)$ & $56.76(13.68)$ & $<\mathbf{0 . 0 0 0 1}$ \\
Total of patients & 60 & 41 & 27 & 128 &
\end{tabular}

Note: Analysis of Variance was used, SD = standard deviation.

\section{DISCUSSION}

This research consisted of a majority of female octogenarians (63\%), emphasizing the feminization of aging ${ }^{(10)}$. The increase in life expectancy has emphasized the need to ensure the elderly not only more longevity, but also happiness, QoL and personal satisfaction ${ }^{(1)}$. However, aging often culminates with the need for care, and caregiving depends on the caregiver's dedication, commitment and affection. According to the results found, $82 \%$ of the older adults had a caregiver.

The finding that the most prevalent marital status in the sample studied was widowed, together with the cases of divorce, comprises data that deserve attention, since the spouse often represents security and stability ${ }^{(10)}$.

Retirement was present in $94.5 \%$ of the sample, an aspect that stands out because it is a moment in which the individual distances himself from productive life. The retirement process affects the individual by generating a discontinuity in his routine, which can represent from leisure and rest to devaluation and sadness ${ }^{(11)}$.

Most of the interviewees (94.5\%) had comorbidities, which present risks and complications that may lead to a decompensation affecting the functionality and autonomy of the elderly, generating a disabling process depending on the case, besides the hospital environment predisposing to a breakdown of social activities. Functional incapacity impacts the family, society, health system and the older adult's own life, since it leads to greater vulnerability and dependence, contributing to the reduction of well-being and QoL in old age ${ }^{(11)}$.

Low schooling was another significant finding in this research, and to elucidate this fact, another study has shown that people's overall capacity to react and respond to everyday challenges is related to their level of schooling. Ordinarily, this older adult profile is prone to less access to health services and few financial resources, reflecting a worse health status ${ }^{(12)}$. Another finding was that older adults with higher schooling had a higher degree of dependence and lower percentages of independence, but another study with elderly residents in the areas covered by the Family Health Strategy (FHS) in the district of Grande Santos Reis, in the municipality of Montes Claros, obtained a different result, that is, a decrease in functional capacity associated with lesser schooling ${ }^{(13)}$.
The literature has pointed out that QoL is likely to reduce following the hospitalization process. Such a fact was observed in a survey, especially with a decrease in well-being and mental health, reduced mobility and self-care capacity, and increased dependence. This reduction may be due to the correlation between disease, old age and the hospitalization context. Accordingly, it is very important that health professionals at the hospital value all dimensions of QoL and apply measures to promote it during and after hospitalization ${ }^{(14)}$.

Often the elderly are faced with professionals who are not always technically able to provide adequate care or are willing to bond, something that favors emotional insecurity in the patient ${ }^{(15)}$. At the same time, during the hospitalization process, older adults lose their references, since this process makes them deal with other personal, social and economic difficulties.

Concerning functionality, the majority of the older adults in this research presented full dependence. A different result was reported in another study carried out in the rural area of Uberaba, where the majority of participants were able to perform all ADL independently ${ }^{(16)}$. Accordingly, hospitals need to create protocols that make it possible to monitor elderly patients' performance of $A D L$ so that it is possible to identify and intervene early in self-care difficulties.

Female older adults had a higher percentage of full dependence and a lower percentage of independence than male older adults. Those with complete secondary and higher education had a lower percentage of independence and a higher percentage of full dependence; and those with complete elementary school had a lower percentage of partial dependence and a higher percentage of full dependence. Partially similar findings were reported in another study evaluating the functional capacity of elderly people enrolled in the FHS in the district of Grande Santos Reis, in the municipality of Montes Claros, where the participants had decreased functional capacity associated with increasing age in women, in older adults with lesser schooling and income of up to two minimum wages ${ }^{(13)}$.

Older adults with partial dependence and independence in this study scored higher in the physical, psychological and environmental domains than did those with full dependence. Partially dependent patients also had higher scores in perceived QoL than did those with full dependence. The decline due to aging hampers the individual's relationship with the environment and impairs his/her performance in ADL, which in turn causes changes of a psychological and social nature. This decline in health may also be related to older adults' psychological well-being. The study of QoL in the elderly is directly related to autonomy-related lifestyle, performance of $A D L$, socioeconomic security, understanding of health-disease symptoms and family relationships ${ }^{(17)}$. 
Partially dependent patients had higher scores in sensory functioning and social participation domains that those with full dependence. Sensory functioning is the facet corresponding to impairment or loss of senses (vision, hearing, smell, taste and touch), compromising daily life, capacity for social integration and participation in activities, leaving the elderly dependent on family care. QoL is associated with the maintenance of autonomy and functional capacity in the elderly ${ }^{(18)}$. Consequently, those who manifest impairment of the senses may experience $a$ reduction in functional capacity, causing damage to the QoL. It is of great importance that the elderly remain active in society, independently, with adequate mental, physical and social health, maintaining the desired well-being. The more active older adults remain, the less they will need their families and health services; therefore, the greater their physical integration into society, the greater the benefits to themselves and society ${ }^{(19)}$.

Partially dependent and independent patients had higher scores in the areas of autonomy, past, present and future activities, and general QoL than fully dependent ones. The domain of past, present and future activities demonstrates the satisfaction with aspects related to the activities that were previously done, to those still being done and to those that could be done. Maintenance of functional capacity contributes to the conduction or concretization of projects, increases self-esteem and well-being and, therefore, improvement of QoL in the elderly ${ }^{(18)}$. In the elderly population, QoL encompasses a number of aspects, such as socioeconomic status, social interaction, intellectual activity, self-care, family support, health status, cultural, ethical, religiosity and functional capacity ${ }^{(19)}$.

Partially dependent participants in the study had higher scores in the death and dying domain than independent participants. The processes of aging and dying are intrinsic to life in all its forms. According to the relevant interpretations and feelings, QoL changes from person to person. It is important to emphasize that the death and dying issue, from the point of view of older adults who experiences the aging process and is closer to death - is an important stage to foster reflection, looking for a positive way of dealing with aging and death-related issues. This may explain the fact that partially dependent participants scored higher on this facet, indicating that they are satisfied about restlessness and death and dying-related fears ${ }^{(18)}$.

\section{Limitations of the Study}

The limitation of this study concerns the fact that it was performed in a single center, with care provided only to patients in the public health system, which may not represent other realities. The results of this study cannot be generalized, since they bring characteristics specific to a certain region of Brazil. However, they provide insight into the functional capacity and QoL of hospitalized octogenarians.

\section{Contributions to the area}

Knowledge of the functional capacity and QoL of hospitalized octogenarians by health professionals can provide these professionals with more precise information about older adults' ability to care for themselves and thus be better able to meet these patients' needs in a personalized way, contributing to a better QoL.

\section{CONCLUSION}

The majority of octogenarians presented full dependence. Female older adults had a higher percentage of full dependence and a lower percentage of independence than their male counterparts. Patients with complete high school and higher education had a lower percentage of independence and a higher percentage of full dependence; and those with complete elementary school had a lower percentage of partial dependence and a higher percentage of full dependence.

Partially dependent and independent patients had higher scores in the physical, psychological and environmental domains than those with full dependence.

Partially dependent patients had higher scores on perceived QoL than those with full dependence. In addition, they had higher scores in the sensory functioning and social participation domains.

Partially dependent and independent patients had higher scores in the domains of autonomy, past, present and future activities, and general QoL than those with full dependence.

Partially dependent octogenarians had higher scores in the death and dying domain than independent ones.

QoL is directly related to the preservation of functionality and autonomy. Older adults experience a decline in their general health status during the hospitalization process, due to the limitations in performing ADL and the health team's lack of knowledge in recognizing the importance of encouragement. The aging process is holistic, and because it is so complex, recurrent strategies and actions are needed so that older adults in a vulnerable environment do not feel so abruptly the consequences of hospitalization. A closer consideration is needed when it comes to elderly people, because sometimes a simple change in behavior or ADL may have consequences that directly affect their QoL.

\section{REFERENCES}

1. Mugueta-Aguinaga I, Garcia-Zapirain B. Is Technology Present in Frailty? Technology a Back-up Tool for Dealing with Frailty in the Elderly: a systematic review. Aging Dis. 2017;8(2):176-95. doi: 10.14336/AD.2016.0901

2. Mirandola AR, Bós AJG. Relationship between physical function and decision-making capacity in oldest-old. Pajar [Internet]. 2015 [cited 2019 May 16];3(2):53-9. Available from: http://revistaseletronicas.pucrs.br/ojs/index.php/pajar/article/download/22532/14149

3. Joaquim FL, Camacho AC, Silva RM, Leite BS, Queiroz RS, Assis CR. Impact of home visits on the functional capacity of patients with venous ulcers. Rev Bras Enferm [Internet]. 2017 [cited 2019 May 16];70(2):287-93. Available from: http://www.scielo.br/pdf/reben/v70n2/0034-7167reben-70-02-0287.pdf 
Functional capacity and quality of life of hospitalized octogenarians Billett MC, Campanharo CRV, Lopes MCBT, Batista REA, Belasco AGS, Okuno MFP.

4. Ran L, Jiang X, Li B, Kong H, Du M, Wang X, et al. Association among activities of daily living, instrumental activities of daily living and health-related quality of life in elderly Yi ethnic minority. BMC Geriatr [Internet]. 2017 [cited 2019 May 16];17(1):74. Available from: https:// bmcgeriatr.biomedcentral.com/articles/10.1186/s12877-017-0455-y

5. Oliveira JR, Rocha Jr PR. Life quality and institutionalized elderly's functional capacity. Rev Kairós [Internet]. 2014 [cited 2019 May 16];17(3):343-53. Available from: https://revistas.pucsp.br/kairos/article/view/23216/16772

6. Mazullo Filho JBR, Silva JMO, Tavares AHS, Rocha GM. Evaluation of quality of life of patients admitted to the intensive care unit of a hospital in Teresina - PI. ConScientiae Saúde [Internet]. 2011 [cited 2019 May 16];10(4):643-49. Available from: http://www.redalyc.org/ html/929/92921260006/

7. Fleck MP, Chachamovich E, Trentini C. Development and validation of the Portuguese version of the WHOQOL-Old module. Rev Saúde Pública [Internet]. 2006 [cited 2019 May 16];40(5):785-91. Available from: http://dx.doi.org/10.1590/S0034-89102006000600007

8. Fleck MP, Louzada S, Xavier M, Chachamovich E, Vieira G, Santos L, et al. Application of the Portuguese version of the abbreviated instrument of quality life WHOQOL-bref. Rev Saúde Pública[Internet]. 2000 [cited 2019 May 16];34(2):178-83. Available from: http://dx.doi. org/10.1590/S0034-891020000000200012

9. Xavier SO, Ferretti-Rebustini REL, Santana-Santos E, Lucchesi PAO, Hohl KG. Heart failure as a predictor of functional dependence in hospitalized elderly. Rev Esc Enferm USP [Internet]. 2015 [cited 2019 May 16];49(5):790-6. Available from: http://www.scielo.br/pdf/reeusp/ v49n5/pt_0080-6234-reeusp-49-05-0790.pdf

10. Almeida AV, Mafra SCT, Silva EP, Kanso S. The Feminization of Old Age: a focus on the socioeconomic, personal and family characteristics of the elderly and the social risk. Texto Contexto Enferm [Internet]. 2015 [cited 2019 May 16];14(1):115-31. Available from: http:// revistaseletronicas.pucrs.br/ojs/index.php/fass/article/view/19830/13313

11. Pereira DS, Nogueira JAD, Silva CAB. Quality of life and the health status of elderly persons: a population-based study in the central sertão of Ceará. Rev Bras Geriatr Gerontol [Internet]. 2015 [cited 2019 May 16];18(4):893-908. Available from: http://www.scielo.br/pdf/rbgg/ v18n4/1809-9823-rbgg-18-04-00893.pdf

12. Gomes GC, Teixeira-Salmela LF, Fonseca BE, Freitas FAS, Fonseca MLM, Pacheco BD, et al. Age and education influence the performance of elderly women on the dual-task Timed Up and Go test. Arq Neuropsiquiatr [Internet]. 2015 [cited 2019 May 16];73(3):187-93. Available from: http://dx.doi.org/10.1590/0004-282X20140233

13. Assis VG, Marta SN, De Conti MHS, Gatti MAN, Simeão SFAP, De Vitta A. Prevalence and factors associated with the functional capacity of the elderly within the Family Health Strategy in the city of Montes Claros, Minas Gerais, Brazil. Rev Bras Geriatr Gerontol [Internet]. 2014 [cited 2019 May 16];17(1):153-63. Available from: http://www.scielo.br/pdf/rbgg/v17n1/1809-9823-rbgg-17-01-00153.pdf

14. Santos G, Sousa L. Quality of life in hospitalized older persons: a comparison of admission to discharge from hospital. Rev Kairós [Internet]. 2013 [cited 2019 May 16];16(2):7-25. Available from: https://revistas.pucsp.br/kairos/article/download/17625/13126

15. Couto FBDE. Caring for the elderly in hospital and home care: what's different? Rev Kairós [Internet]. 2015 [cited 2019 May 16];18(Esp 19):5776. Available from: https://revistas.pucsp.br/kairos/article/download/26598/19027

16. Tavares DMS, Gávea Jr SA, Dias FA, Santos NMF, Oliveira PB. Quality of life and functional capacity of elderly people residents in rural area. Rev Rene [Internet]. 2011 [cited 2019 May 16];12(Esp):895-903. Available from: http://periodicos.ufc.br/rene/article/view/4458/3379

17. Gadelha VB, Sardeli AV, Santos WM, Ribeiro CP, Moraes DFG, Cavaglieri CR, et al. Importância da força muscular para a qualidade de vida de idosos sedentários. Rev Bras Qual Vida [Internet]. 2017 [cited 2019 May 16];9(2):153-64. Available from: https://periodicos.utfpr.edu.br/rbqv/ article/view/5916

18. Almeida VC, Meira SS, Gomes FV, Souza MC, Santos VC, Anjos KF. Quality of life in elderly people who experienced falls. Rev APS [Internet]. 2014 [cited 2019 May 16];17(4):530-6. Available from: http://periodicos.ufjf.br/index.php/aps/article/view/15319

19. Oliveira DAS, Nascimento Jr JRA, Bertolini SMMG, Oliveira DV. Participation of elderly in social groups: quality of life and functional capacity. Rev Rene [Internet]. 2016 [cited 2019 May 16];17(2):278-84. Available from: http://www.periodicos.ufc.br/rene/article/view/3017/2333 